\title{
Minimum Wages and Poverty in a Developing Country: Simulations from Indonesia's Household Survey
}

\author{
Kelly Bird and Chris Manning
}

\begin{abstract}
This study focuses on the efficiency of minimum wage policy for poverty reduction, taking Indonesia as a case study. A simulation approach assesses who benefits and who pays for minimum wage increases. On the benefits side, the rise in minimum wages boosts incomes in households with low wage workers. However, increases in wage costs are passed on through higher consumer prices. As a result, three out of four poor households lose in net terms, even when we assume no job losses. The findings suggest that minimum wages are unlikely to be an effective antipoverty instrument, at least for Indonesia.
\end{abstract}

Key Words: Minimum Wages, Poverty, Income distribution, Indonesia

JEL Classification: I31, J33, J38, O15

Email: KBird@cbn.net.id; Chris.Manning@anu.edu.au 


\title{
Minimum Wages and Poverty in a Developing Country: Simulations from Indonesia’s Household Survey
}

\author{
Kelly Bird and Chris Manning ${ }^{1}$
}

\section{Introduction}

In recent years, there has been a renewed interest in policies which seek to cushion workers from harmful effects of globalization (Greenaway \& Nelson, 2001; Elliot \& Freeman, 2003). This has given new impetus to an old debate on minimum wage policy and its implications for employment and labor welfare in both developed and developing countries. On the one hand, it is argued that minimum wages can reduce poverty by boosting the incomes of households with low wage workers. Influential research in developed countries has argued that increased minimum wages may have little or no effect on employment, and the poor stand to gain (Card \& Krueger, 1995). On the other hand, opponents of minimum wage legislation argue that minimum wage policy has had a limited impact on poverty, mainly because most poor families do not have minimum wage workers (Burkhauser, Couch \& Wittenburg, 2000).

The debate raises the broader question of whether minimum wage policy is an effective antipoverty instrument, in an international policy environment where poverty reduction strategies are at the centre of many government programs (W

inters, McCulloch \& McKay, 2004). To answer this question we need to examine how increased minimum wages impact on household incomes and cost of living of workers and their families, in addition to their direct effect on employment.

A second, related issue involves the distributional impact of minimum wages. In this case, the question relates to the extent to which the poor benefit from a minimum wage hike relative to other income classes. In short, a minimum wage policy is 'pro-poor' (and hence a well 'targeted' policy) if it has a disproportionately positive effect on the incomes of poor households compared with other income groups (Dollar \& Kray, 2001). 
This paper addresses these issues. It seeks to examine the impact of a minimum wage hike on incomes and the cost of living of poor households, in the context of their broader distributional effects in a developing country. The focus of the study is Indonesia, where poverty reduction strategy programs (PRSP) have become an important element in most government programs since the economic crisis of 1998 (Bird and Manning, 2003). An active minimum wage policy has been adopted partly as a tool to reduce poverty, through a focus on the level of wages relative to the minimum needs of wage earning families (Manning, 2003). Like in other countries, research has focused on the effects on employment rather than income distribution and poverty. $^{2}$

The main aims of the paper are three fold. First, it seeks to illustrate rough orders of magnitude in the impact of a moderate increase in minimum wages on the poor, and other income classes. Second, rather than focus on the outcomes alone, it aims to demonstrate the channels through which minimum wage increases might affect real labor incomes and poverty. And finally, it attempts to throw light on the distribution of net income effects, both among the poor and between the poor and better-off households. This has important political economy implications. For example, households that gain may be more organized wage earners, whereas the losers might consist of a much larger group of more dispersed consumers. Such a finding would provide a compelling explanation of why a minimum wage policy which may hurt the poor, on balance, might still be implemented.

Given difficulties in modeling the longer term, general equilibrium effects, the paper concentrates on the shorter term impact on incomes, assuming first that employment remains unchanged, and the effects of minimum wages are principally passed on to consumers in the form of higher prices. Later, we relax the no-job-loss assumption in separate simulations to examine the distributional implications of employment losses.

Flagging some of the main results, we find that the increase in minimum wages helps some poor households escape out of poverty. However, the majority of poor households do not have a minimum wage worker, as many operate in the informal or uncovered sector. They are likely to be penalized through higher prices, as a result of the increase in wage costs. In short, our findings 
suggest that an aggressive minimum wage policy like that adopted in Indonesia is likely to be a blunt instrument for poverty reduction.

The organization of the paper is as follows. Section 2 briefly outlines the framework for analysis. Section 3 provides a background to the Indonesian labor market and minimum wage policy. Section 4 sketches out the empirical methodology while section 5 presents the simulation results for the actual increases in minimum wages in Indonesia in 2003. The results are presented in three parts: quantifying the additional wage benefits to households, the extra expenditure households must pay for the same bundle of goods consumed after the minimum wage increase and, third, the net benefits accruing to each household, across different income groups, and especially the poor. Section 6 repeats the simulations taking into account employment losses. Section 7 offers some conclusions and draws attention to some qualifications of relevance to policy formulation.

\section{2. $\quad$ Framework of Analysis}

Some economists view minimum wage policy as mainly an income distributional issue whereby some persons gain and others will lose from a minimum wage hike (Card \& Krueger, 1995: p27: MaCurdy \& McIntyre, 2001: p1). However, many previous empirical studies have adopted only a partial distribution analysis. They simulate the distribution of wage gains across income groups, but do not incorporate the costs of the minimum wage hike such as employment losses or consumer price increases. ${ }^{3}$ Implicitly these studies ignore other social dimensions of minimum wage policy. However, taking a broader framework one can ask additional questions: do the benefits go to the intended target, poor households, and how are these benefits financed (who pays)? A policy is well targeted if the benefits accrue disproportionately to the poor and the costs fall disproportionately on the non-poor.

This paper draws on other simulation studies to take into account of both the benefits and costs of the wage increase, using household-level data. On the benefits side, we assume that an increase in minimum wages boosts the incomes of households with at least one minimum wage, or low wage, worker. We first assume a world of no job losses. As noted, while controversial, research in developed countries suggests that this may not be a totally unrealistic assumption, at 
least in the short run. ${ }^{4}$ On the cost side, it is assumed that producers pass on the full increase in wage costs to consumers through higher final prices. The net effects on households are then simulated, holding their consumption quantities and hours of work constant, at levels prior to the minimum wage adjustment. Both assumptions follow the approach adopted by MaCurdy \& McIntyre (2001). We also adopt the same assumption that the gains to beneficiaries are cancelled out by losses to those adversely affected. In this way, the simulation model is 'closed' by equating total benefits with total costs.

It is recognized that these are strong assumptions and are only likely to be relevant in the short run and for small increases in minimum wages. Substitution effects and the structure of product markets will, of course, influence prices and the distribution of benefits and costs across income classes. Nevertheless, we believe that the findings represent a reasonable approximation of the impact on household welfare, for small changes in the minimum wage and final consumer prices.

\section{The Indonesian Labor Market and Minimum Wage Policy}

Indonesia is interesting as a focus for this study for several reasons. First, labor market structure is typical of a low income developing country. It has a small modern or formal wage sector which stands to gain from labor regulations. The rest of the workforce is engaged in the 'uncovered' informal sector (Table 1). Second, as noted, Indonesia has adopted a vigorous needs-based, minimum wage policy as part of a broader social safety net strategy.

Minimum wage regulation is not new in Indonesia. It had already been a key element in labor policy for close to a decade prior to the downfall of the Soeharto government in 1998 (Manning, 1998). The emphasis has been on consumption levels of the poor, as reflected in the adoption of an index of minimum living needs (the KHM - Kehidupan Hidup Minimum from the mid 1990s), as the main basis for assessing minimum wages relative to an absolute standard of the minimum needs of workers. The standard was based on regular estimates of the cost of living made by regional government Manpower Offices, according to price changes in a basket of 43 items.

In the post Soeharto era, a major change in the basic framework for setting minimum wages occurred in January 2001. The authority for setting regional minimum wages was decentralized to provincial governors. ${ }^{5}$ However, the regulatory framework has remained the responsibility of 
the Central Government, including the issuing guidelines for the consumption basket on which the basic needs of wage working families are assessed.

For our later discussion of poverty, three points are worth noting regarding both the level of minimum wages and annual adjustments across regions.

- First, the standard for evaluating the adequacy of minimum wages - prices of 43 items has been high by other measures of disadvantage in Indonesia. ${ }^{6}$

- Minimum wages had become much more 'binding' relative to average wages of youths, females and low educated workers. Compliance with minimum wages increased with the freeing up of trade unions after the fall of the Soeharto in 1998, which had exerted tight controls for more than 25 years (Suryahadi, Widyanti, Perwira \& Sumarto, 2003). By the year 2000, minimum wages were very close to average wages for these groups of workers.

- Third, annual revisions to the minimum living needs estimated by the Ministry of Manpower, were typically much higher than estimated increases in the CPI. The differences were large enough to raise some doubt regarding the reliability of changes in minimum needs as a yardstick for minimum wage revisions. ${ }^{7}$

Nevertheless, it is important to note that coverage of minimum wage and other labor legislation is limited to wage employees. The informal sector, including the self-employed are not included. As shown in Table 1, regular wage employees accounted for about $27 \%$ of the total workforce, while the self-employed and unpaid family workers make up the remaining about 70\% in 2002. However, even among employees, compliance with minimum wage legislation is likely to vary across different types of occupations. For example, it has been estimated that, about $30 \%$ of wage employees in urban areas received monthly wages below the minimum rate in the year 2000 (Suryahadi, Widyanti, Perwira \& Sumarto, 2003).

\section{Approach and Methodology}

In the simulation framework we distinguish between two types of households. The first type has at least one household member working as a low wage employee in the 'covered' formal sector, and therefore these households stand to gain from a minimum wage increase. A low wage employee in the formal sector is defined as a regular wage employee earning a monthly wage in 
2002, which was below the new minimum set for 2003. The second type of household is one that does not have a low wage employee working in the formal sector, and hence this household cannot (by definition) benefit from a hike in the minimum wage. These households either have members employed above the minimum rate in 2003, or work in the informal sector.

How an economy pays for a minimum wage increase may be less obvious than how people benefit. The cost of higher wages must be paid by someone. MaCurdy \& McIntyre (2001) suggest three possible groups may pay for the minimum wage increase, depending on how firms respond to the increase in wage costs.

- First, employers may reduce employment or adjust other aspects of the employment relationship (e.g., less fringe benefits, reduced working hours). In this case, workers pay.

- Second, firms may absorb all of the wage increase through lower profits. In this case, owners of capital pay, assuming the firm is sufficiently profitable to absorb the extra costs.

- Finally, employers can increase prices so that consumers pay for the minimum wage increase, and accept the risk of losing customers as a result.

In the simulation, it is first assumed that producers do not reduce employment or hours of work, and that shareholders do not pay by reducing profits. Although the extra resources needed to cover higher labor costs could theoretically come out of profits, this source of adjustment may not be significant. Firms in low wage industries (garments, footwear, restaurants and retail stores) are typically highly competitive. In the short run, employers in low-profit-margin industries will raise prices to reduce exposure to goods produced by low wage labor.

With regard to the price response, firms that compete in tradable-goods markets and are price takers. Lowering exposure to low wage labor is the only option for these firms when wage costs rise. However, many firms that employ minimum wage workers compete in non-tradable-goods industries such as retail, restaurants, and transportation. For these industries, a minimum wage increase is likely to represent an industry-wide increase in costs. Prices for low goods produced by low wage labor will rise, and output would also fall, depending on price sensitivity of consumers. Thus, some of the burden of the minimum wage increase falls on consumers of lowwage products. ${ }^{9}$ 
Of course, in order to have no job or profit losses, consumers must continue to purchase the same amount of low wage goods at the higher price. Thus, following MaCurdy \& McIntyre (2001), we make four assumptions when we simulate the minimum wage effects:

- All increased labor costs are passed on in the form of higher prices

- Low-wage workers remain employed at the same number of hours after the minimum wage rises (demand for low wage labor is perfectly inelastic in the short run).

- Consumers do not reduce consumption as prices rise (product price elasticities of demand are perfectly inelastic in the short run)

- Foreign consumers do not reduce consumption of Indonesia's exported goods as prices rise.

Taken together, the four assumptions allow us to simulate the expected effects of minimum wage increase in a relatively simple manner. Of course these assumptions may not hold in reality, especially in the medium to longer term future, since several violate the general equilibrium conditions of substitutability. In practice, producers will use a combination of all three strategies, depending on the conditions of the market. For example, in a competitive market with mobile capital, producers are more likely to respond to an increase in wage costs through a combination of increases in their product prices and reductions in employment. With increases in product prices, one would expect both income and price substitution effects to affect the real level and composition of household consumption. In turn, this would affect industry profit margins and employment across sectors. Also, increases in the relative price of low wage labor would shift factor demand towards products employing more skilled labor and capital in the long run.

Despite these complications, we believe that an assessment of these minimum wage effects in a simulation environment facilitates a better understanding of the distributional implications of increases in the minimum wage for the poor. It demonstrates the key adjustment processes, both of which are of interest in policy makers. If one tries to model the consequences for firms of using all three strategies at once, the effects in each case are diluted. It is thus difficult to detect the effects on employment, prices, household consumption, and profits empirically with precision. However, in the second simulation, we relax our no-job-loss assumption.. 


\section{Data and Methodology}

Indonesia has a rich micro-database on household income and expenditure to evaluate the effects of minimum wage increases on income distribution and poverty. The Central Bureau of Statistics (CBS) produces a nationally representative survey of household income and expenditure known by its acronym SUSENAS. The SUSENAS survey covers some 200,000 households and provides detailed information on household members' characteristics, occupational status, wages, hours of work, as well as household expenditure on goods and services. This allows us to identify low wage workers and simulate their additional earnings from the minimum wage increase.

Figure 1 shows the steps in developing our simulations. We use SUSENAS to simulate the additional earnings of each identified low wage worker after an increase in the statutory minimum rate, assuming that all employees continue to work at the same hours as in $2002 .{ }^{10}$ For households with more than one worker, we aggregate across household members to derive the increase in total household income $(\Delta \mathrm{Y})$. The increase in income is estimated by the following equation:

$\Delta Y_{j, 2003}=\sum_{i}^{n} \Delta W_{i, 2003} * H R_{i, 2002}$ where $\mathrm{i}=1 \ldots \mathrm{n}$ low wage workers in household $\mathrm{j}, \Delta \mathrm{W}$ is the change in the low wage worker's hourly wage rate in 2003 and HR is the 'ith' worker's hours of work in 2002

In simulating the costs, we assume that firms pass on the increase in wage costs in the form of higher prices. To demonstrate the effects, a three sector model comprising agriculture, manufacturing and services is adopted. Using data in SUSENAS, we can identify how much total wage costs rise in each sector. The Input-Output table is used to translate higher labor costs into total production costs in each sector. Once household purchases of goods and services are mapped to the three sectors, we use SUSENAS to relate price increases to goods actually consumed by households. We then simulate the extra expenditure $(\Delta \mathrm{E})$ that each household $\mathrm{j}$ must pay to consume the same bundle of goods as before the wage increase: 
$\Delta E_{j, 2003}=\sum_{i=1}^{3} \Delta P_{i, 2003} * Q_{2002}$ where $\mathrm{i}=1 . .3$ product sectors, $\Delta \mathrm{P}$ is change in price of good $\mathrm{i}$ in 2003, and Q is the quantity of good i consumed in 2002. The final step in our simulations us to calculate the net benefits for each household ( $\Delta \mathrm{Y}-\Delta \mathrm{E})$.

\section{Who Benefits and Who Loses from the Minimum Wage Increase?}

This section identifies low-wage earners and examines how the additional benefits from a minimum wage increase are distributed across households by income group. The emphasis is on the type of households that are likely to be the main targets of minimum wage policy. ${ }^{11}$ In presenting the findings, we group households according to their income position relative to the poverty line (also known as income-needs ratio), since household poverty depends on both total income (of which wages are one component) and the size of the household. ${ }^{12}$ This approach allows us to assess the impact on economic well-being of households of different sizes. It also allows us to consider what share of the benefits from the minimum wage hike goes to poor households.. Therefore, we categorize households in three groups as follows: ${ }^{13}$ (i) poor households with an income-needs ratio below 100\%; (ii) near poor households with an incomeneeds ratio between 100\% and 150\%; and (iii) non-poor households with income-needs ratio above $150 \%$.

\subsection{Who are the beneficiaries?}

To determine households that benefit from the minimum wage increase, we first identify which households in 2002 include at least one wage worker earning less than the new minimum rate set in January 2003 (Table 2). The first column shows the share of total households in each incomeneeds group. The second column shows the share of households that have a low wage worker and final column shows the distribution of households with low wage workers, across the different income classes. As we can see from the first column, the poverty rate was about 17\% for all households in Indonesia in 2002 (i.e., households with per capita income less than the poverty line). Another $34 \%$ of households are classified as near-poor and $49 \%$ as non-poor.

Perhaps surprising for a developing country, the low wage population is remarkably evenly spread across income-needs thresholds. Overall, 23.5\% of all Indonesian households have at 
least one household member employed on a low wage in the formal sector. Twenty-five per cent of households living in poverty have a low wage worker. This share decreases only slightly for the highest income group (22\% for households with per capita incomes at least 3 times higher than the poverty line).

Why do so many households in the higher income quintiles have household members earning a low wage? This question is important because the Indonesian government is considering revamping the minimum wage to reflect the 'decent living needs' of a household of four, in place of the current policy which focuses on the needs of a single worker. ${ }^{14}$ Demographic characteristics of low wage earners by per capita income relative to the poverty line provide part of the answer. Table 3 shows that the 'average’ low wage worker living in a poor household has different characteristics from the 'average' low wage worker residing in a better-off household. Low wage workers in poor and near poor households are mainly low educated workers (78\%), adults over the age of 24 years (68\%), male (63\%) and married (58\%). These percentages decline as we move from poor to non-poor households. The differences are most striking between poor households and those households with per capita incomes higher than 300 per cent of the poverty line. The data suggest that whereas the average low wage worker in poor households is more likely to be the main breadwinner in a household, the average low wage worker in wealthy households is more likely to be a secondary earner.

Do the benefits from the minimum wage increase accrue disproportionately to poor households? Figure 2 seeks to answer this question. From Figure 2 we see that the benefits are divided among the different income-needs groups about equal to their distribution in the population. Poor households account for $17 \%$ of the population and receive about $17 \%$ of the benefits. Non-poor account for $49 \%$ of the population and receive about half of the benefits. This suggests that minimum wage policy is not an efficient way of boosting the incomes of poor households. ${ }^{15}$

\subsection{Who Pays for Minimum Wage Increase?}

The second part of our study simulates the extra expenditure households must pay for the same bundle of goods consumed in 2002, after the minimum wage increase in 2003. In contrast to the benefits, estimating the costs to households is more challenging. While about one quarter of households benefit from the increase in the minimum wage, all households are assumed to pay through higher consumer prices. The minimum wage increase results in higher labor costs due to 
both higher wages and higher social security contributions. Firms respond to higher labor costs by increasing prices; consumers of goods produced by low-wage labor face higher prices after the wage increase.

To summarize the methodology (discussed in Section 4 above), the procedure is as follows:

- Using information in SUSENAS on sectors employing low-wage workers, we calculate by how much total wage costs rise in different sectors.

- We then use the input-output table to translate higher industry wage costs into total production costs. The Input-Output table allows us to trace both the direct and indirect labor costs. ${ }^{16}$ It is through this feedback process that the price shock from the minimum wage hike spills over to the entire economy.

- We then match sector of employment with sectors according to household purchases of goods and services. We use SUSENAS to relate 'implicit' price increases to the goods actually consumed by households

- Dividing the additional production costs by total household expenditures on each good yields a percentage cost increase (often referred to as an 'implicit' incremental tax rate or 'implicit' price). The implicit tax rate tells us the rate at which consumer prices must increase to cover additional costs. These prices ensure total benefits to households with low wage workers equate to total costs paid by consumers (Macurdy \& McIntyre, 2001; 17).

- We use these implicit prices to simulate the additional costs to households in 2003, assuming households continue to purchase the same bundle of goods as in the previous year.

The average increase in minimum wages of 13\% in 2003 raised earnings of workers by approximately Rp. 7.7 trillion (or US\$800 million) or Rp. 8.1 trillion from an employer's perspective, if social security contributions are included. Domestic consumers do not pay for the full Rp. 8.1 trillion cost. Rather, in our simulation framework, the costs are shared between domestic and foreign consumers, depending on the share of domestic production exported (assuming that foreign consumers do not reduce consumption of Indonesian exported goods as prices rise). According to the I-O table, about $23 \%$ of total domestic output is exported. ${ }^{17}$ Thus, we assume that domestic consumers pay 77\% of additional production costs (or Rp7.2 trillion). 
The increases in the implicit prices for the three product groups range from $0.7 \%$ for agriculture, $1.3 \%$ for manufactured goods and $2.5 \%$ for services. While these increases are small and provide some justification for our assumption of no price substitutability, most households facing these higher prices do not receive additional earnings. Higher prices will require either a reduction in consumption or a cut in savings. As noted, these implicit prices should be treated as maximum increases, as they assume no price substitutability in the system, and no-job-losses or profit reductions.

\section{The Distribution of Costs Across Households}

These implicit tax rates allow us to calculate the distribution of costs across households, just as we previously calculated the distribution of benefits across households. Nationally, domestic consumers pay Rp7.2 trillion more for goods and services after the minimum wage increase. As for benefits, the different costs are calculated relative to the poverty line for households distinguished by income group.

On average, each household pays Rp.137,000 (US\$15) more per year for their purchases after the minimum wage increase (Table 4). Households living in poverty pay Rp.66,000 (or 1.3\%) more on average per year for their purchases. The amount increases as we move from poor to better-off households. Households with per capita income at least three times the poverty line pay Rp.389,000 (or 1.8\%) more per year for their purchases. Non-poor households bear a slightly higher percentage increase in costs through a higher share of their expenditure on utilities and services (these goods have a higher minimum wage content compared with agricultural goods). ${ }^{18}$

Figure 3 presents the share of total costs by per capita income relative to the poverty line. On the benefits side, it was noted that households living in poverty received a smaller share of the gains than households with incomes double or triple the poverty line. On the cost side, households living in poverty pay only $8.4 \%$ of the costs, compared to with the $69.4 \%$ paid by the non-poor. The costs are better 'targeted' than the benefits.

\subsection{Net Effects and the Impact on Poverty}

We now bring the benefits and costs together to examine the net effects across different households, and to explore how these net effects impact on the transition of households in and out of poverty and near poverty. 
Figures 2 and 3 presented earlier show that poor households as a group are better off after an increase in the minimum wage. They receive $17 \%$ of the benefits but only pay $8 \%$ of the costs. Table 5 shows that poor households in aggregate receive Rp.668 billion (US\$74 million) in net benefits, near poor receive Rp.1.1 trillion (US\$114 million), while non-poor group lose Rp.1.2 trillion (US\$131 million). Thus, there is some redistribution of income from the rich to the poor as a result of minimum wage increases.

However, the aggregate figures hide distributional effects within income groups. Table 5 presents these net effects by household group. In each case, we distinguish households with low wage workers in the formal sector from other households. This distinction is the key understanding the impact of minimum wage increases on income distribution. Only some households with a wage earner benefit, but all households pay through higher prices.

Net benefits are calculated as the average benefit to a household with a low wage worker minus the average cost the household will pay for higher priced goods. For example, 25 per cent of poor households have a low wage worker in the formal sector and therefore benefit from a minimum wage hike. These households on average receive Rp.567,000 (US\$ 61) in benefits. On average, they pay Rp.66,000 in higher prices. As shown in Table 5, their net benefit is Rp.501,000 (US\$54).

In contrast, households with no low wage employee in the formal sector do not receive any benefits. But they have to pay the costs through higher consumer prices. The 75 per cent of poor households without a low wage worker on average pay Rp.66,000 in higher prices but receive no benefit.

The table shows that about $40 \%$ of the redistribution of income to poor households occurs between poor households. Given that only the 25 per cent of poor households with a low wage employee received a net benefit, whereas the other 75 per cent lost, the 2003 minimum wage increase is equivalent to taking Rp.66,000 from three poor households (totaling Rp.200,000), plus Rp.301,000 from non-poor households, summing to Rp.501,000. This is given to the fourth poor household. 
The central goal of any poverty reduction strategy is to reduce the number of poor households. Indeed, policy makers will often measure the success of a strategy in these terms. Table 6 presents findings of simulations for households that move out of poverty and near-poor households that fall into poverty. Households with low wage workers get a boost in income, and therefore in consumption, equal to the additional earnings from the minimum wage hike. Other households do not receive any benefits, but have to pay more for higher-priced goods: that is, these households experience a reduction in their real incomes. ${ }^{19}$

Looking at Table 6, we see that prior to the minimum wage increase 9.2 million households were classified as poor. After the minimum wage increase, some half a million households escape poverty and move into the near-poor category, and out of poverty. On the other hand, almost 410,000 near-poor households (who received no benefits) fall into poverty as a result of having to pay higher prices. Overall, the number of poor households declined by 95,000 to 9,066,094, or a fall of one per cent on 2002. On the other hand, the total number of near-poor households increased slightly.

From the simulations reported in tables 5 and 6 , it is clear that aggregate figures on poverty mask the redistribution of income between households. One in four poor households are unambiguously better off and 500,000 of these households escape poverty. On the other hand, three out of four poor households are ambiguously worse off from pay higher prices. Further, another 410,000 previously near poor families fall into poverty as a consequence of the price increases.

\section{Relaxing the no-job-loss assumption}

One limitation of the above simulations is the assumption that producers finance the minimum wage hike through higher consumer prices and not through employment cuts. If the no-job-loss assumption is relaxed, the aggregate benefits would be reduced and all households would be faced with smaller price increases. The impact on the distribution of benefits across income groups depends mainly on the distribution of job losses within the low wage population. As noted earlier, the international debate on whether minimum wages cause job losses, in aggregate, remains controversial. Nevertheless, some studies for developing countries show that less skilled workers and youths are more likely to lose their jobs from minimum wage hikes compared with 
more skilled workers and adults, as this group of workers is disproportionately represented among minimum wage workers. For example, a recent study in Indonesia estimated that a one per cent real increase in the minimum wage reduced employment of low educated workers as much as $0.2 \%$ (Suryahadi, Widyanti, Perwira \& Sumarto, 2003). In this case, employment losses might be expected to disproportionately affect poor households, bearing in mind that less educated, low wage workers are more likely to reside in poor or near-poor households (see the data cited in Table 2 above).

Additional simulations were undertaken that assume job losses. The employment elasticity of 0.2 found by Suryahadi et al. was assumed, as an example, to estimate job losses among less educated workers in each income group. There were approximately 12 million less educated workers in the 'covered' wage sector in 2002. Using this elasticity, an $11.5 \%$ real increase in minimum wages in 2003 would result in about 280,000 estimated job losses among this group. The fall in employment reduces aggregate benefits (and therefore wage costs) by about 16\%, compared with the benefits simulated under the no job loss assumption. With a lower increase in wage costs, implicit final prices rise by about $1.2 \%$ compared to $1.5 \%$ under our first simulation.

In these simulations, the job losses occur disproportionately among poor and near poor households, given that a higher proportion of low educated, low wage workers reside in poor households. Almost one quarter of the simulated job losses occur among poor households, 37\% of job losses occur among near-poor households, and the remaining 38\% of jobs losses are in non-poor households. The simulated distribution of benefits does change, although only slightly. Whereas poor households receive about $16.8 \%$ of the benefits when there are no job losses, they receive about $16.3 \%$ of the benefits when there are job losses of the magnitude assumed in our study (See Annex 1). In contrast to poor households, non-poor households' share of the benefits increases from $48.8 \%$ to $49.7 \%$.

Table 7 presents the simulated net effects by income group, assuming that producers finance the increase in the minimum wage through a combination of employment cuts and higher final prices. For comparison, the simulation results for the 'no-job-loss' scenario are reproduced from Table 5. From Table 7, it is apparent that the average gains to poorer households with low wage workers are smaller when there are job losses. For example, in net terms, a poor household with 
low wage workers receives $18 \%$ less than the average gains when we assume no job losses. Conversely, a poor household with no low wage worker loses less because price increases are smaller.

\section{Conclusions}

At the beginning of the paper, it was noted that minimum wage policy is often cited as one policy instrument for helping the poor. Hence the need to assess the effectiveness of minimum wage policy as an anti-poverty instrument. An anti-poverty program is efficient and well targeted if the benefits accrue disproportionately to the poor, and the costs fall disproportionately on the non-poor.

Our findings suggest that the minimum wage policy is unlikely to be an effective antipoverty reduction instrument, at least for Indonesia. Minimum wage legislation does boost the incomes of some poor families and some do escape poverty. But the majority of poor households may actually be penalized through higher consumer prices. Our simulation results indicate that only about $17 \%$ of the additional earnings from the minimum wage hike in 2003 were likely to flow to poor households, another $34 \%$ of the benefits flow to the near-poor, while half of the benefits accrue to non-poor households. Moreover, the examination of net benefits reveals that only one in four poor households gain through higher incomes, while three out of four poor households lose through higher prices. When employment losses are included, the net benefits to the poor are actually smaller, assuming that unskilled job losses have a disproportionately greater impact among poor households.

In general the simulation exercise also highlights the much more concentrated nature of the gains among workers - both in gross and net terms - versus the smaller, but much more dispersed nature of the losses among consumers. The simulations thus help us understand why the Indonesian government has followed an active minimum wage policy, especially in the recent period of greater labor activism, even though a significant share of the population might be penalized. Our simulations results also tell us that it is not sufficient to examine the employment effects alone. One also needs to assess the impact of potentially larger costs, such as the price effects. 
How do our results compare with findings from other countries? Based on a similar approach, the findings of Macurdy \& McIntyre (2001) for the U.S.A are surprisingly similar to those for Indonesia. Poor households in the U.S.A account for 15 per cent of the population and they received about 15 per cent of the benefits. MaCurdy and McIntyre also found that three out of four low income households were unambiguously worse off due to higher consumer prices. Neumark \& Wascher (1997) adopted an econometric approach [logit model] and found that increases in the U.S.A Federal minimum wage rate during the 1980s increased the probability of poor households escaping from poverty, and previously non-poor households falling into poverty. Numbers for the non-poor slightly outweighed those for the poor.

Unfortunately there have been fewer studies on minimum wages and poverty in developing countries, and no simulations of the kind presented in our paper. ${ }^{20}$ The majority of studies rely on cross-country analysis and several find that reductions in poverty rates were larger in countries with greater increases in minimum wages. ${ }^{21}$ However, cross-country studies have well known weaknesses that can bias estimation results (Winters, McCulloch \& McKay, 2004). The cross sectional (or panel) assumption that the same model and parameter set applies to all countries is questionable; so too is the cross-sectional assumption that the data reflects a stable steady-state relationship.

Recent empirical work on poverty emphasizes the need for detailed case studies of particular countries and analysis at the household level (Ravallion, 2001, 2003; Winters, McCulloch \& McKay, 2004). Such an approach has been adopted in this paper. By using household-level data we can gain greater insights into the distributional effects of a specific policy that can not be easily done using aggregated data across-countries.

\section{Some Qualifications}

The findings of the study need to be qualified in three ways. We assumed no profit losses from the minimum wage increase, no price substitution effects and, finally, the study did not incorporate spillovers to the informal sector.

The outcomes are likely to change in two ways if we allowed for profit losses in our simulations. The benefit side would not change, but there would be smaller price increases because some portion of the wage increase is financed by shareholders. To incorporate profit losses we would 
need to quantify the distribution of profits from firms with low wage workers. This information is not available. It is likely, however, that this change would increase the net benefits accruing to lower income households, given that wealth is more concentrated than income (see Macurdy \& McIntyre, 2001).

Second, we assumed no price substitution in the model: consumers buy the same bundle of goods, despite higher prices. In reality, consumer demand would shift away from higher priced goods produced by low wage labor to other goods depending on price and income elasticities. Consequently, additional costs facing families would not be as high as simulated in this paper.

A final qualification relates to the failure to account for potential spillovers to the informal sector, and feedbacks to household incomes and poverty. The impact on the informal sector depends on the extent of job losses in the formal sector, and whether there is capital flight to the informal sector. If job losses occur, more workers enter the informal sector and this puts pressure on earnings and household incomes. Since informal workers are more likely to live in poor households, increased competition and lower earnings in the informal sector are likely to hurt poor households disproportionately. On the other hand, if increased labor costs in the formal sector encourage capital flight to the informal sector, this may offset some of the pressure on earnings in this sector.

To incorporate all these equilibrium conditions requires an elaborate general equilibrium model. Thus, application of a CGE model which seeks to predict the impact of minimum wages on poverty would complement our simulation. However, the beauty of the simulation approach is that it allows an assessment of the individual effects on prices, and household incomes and consumption in a relatively simple manner. It is harder to trace the impact of these individual effects using a CGE model.

Finally, as with other studies of this genre, we reiterate that the assumption of no price substitution may be a reasonable approximation for an experiment in which there are small changes in consumer prices, especially when we are focusing mainly on short-run adjustment benefits and costs. It is short run considerations that are typically the main consideration of policy makers in taking controversial decisions such as raising minimum wages. 


\section{References}

Alatas, V. and L. Cameron (2003),'The Impact of Minimum Wages on Employment in a Low Income Country: An Evaluation Using the Difference-In-Difference Approach', World Bank Policy Research Working Paper 2985, March.

Bird, K. and C. Manning (2004), 'Economic reform, labor markets and poverty: the Indonesian experience', in K. Sharma (ed) Trade Policy, Growth and Poverty in Asian Developing Countries, Routledge, U.K, pp. 74-94.

Baker, M., D. Benjamin and S. Stanger (1999), 'The Highs and Lows of the Minimum Wage Effect: A Time Series Cross-Section Study of the Canadian Law,' Journal of Labor Economics, 17, pp. 318-50.

Bell, L (1997), 'The Impact of Minimum Wages in Mexico and Colombia', Journal of Labor Economics, Vol. 15(3), pp. 103-135.

Burkhauser, R., Couch K, and D. Wittenburg (2000), 'A Reassessment of the New Economics of Minimum Wage Literature Using Monthly Data from the CPS', Journal of Labor Economics, Vol. 18(4), pp. 653-80.

Burkhauser, R., and M. Harrison (2000),'A Review of Recent Evidence of the Minimum Wage on the Working Poor', in A. Rees (ed) Low wage Commission International symposium on Minimum Wage Policy, Occasional Paper No. 4 London: Low Pay Commission January 2000.

Card, D and A. Krueger (1994), 'Minimum Wages and Employment: A Case Study of the Fast Food Industry in New Jersey and Pennsylvania,' American Economic Review, Vol. 84, pp. 772-93.

Card, D. and A. Krueger (1995) Myth and Measurement: The New Economics of the Minimum Wage, Princeton University Press, Princeton.

Dollar, D. and A. Kraay (2000), Growth is Good for the Poor,' Policy Research Working Paper 2587, World Bank, Washington D.C..

Elliot, A. B. and R. B. Freeman (2003) Can Labor Standards Improve Under Globalization, Institute for International Economics, Washington D.C.

Greenaway, D. and D. Nelson (2001) 'Globalisation and Labour Markets: Literature Review and Synthesis’, GEP Research Paper Series 01/29, University of Nottingham.

Harrison, A. and J. Scorse (2004), 'Moving Up or Moving Out? Anti-Sweatshop Activists and Labor Market Incomes,'. NBER Working Paper 10492, Cambridge.

Horrigan, M. and R. Mincey (1993), "The Minimum Wage and Earnings and Income Inequality”, in S. Danziger and P. Gottschalk eds., Uneven Tides: Rising Inequality in America, Russell Sage Foundation: New York, pp. 251-75.

Islam, I and Nazara S. (2000) 'Minimum Wages and the Welfare of Indonesian Workers', Occasional Discussion Paper Series No. 3, ILO, Jakarta.

Kosters, M. (1996) The Effects of the Minimum Wage on Employment, AEI Press, Washington D.C.. 
Livingstone, I. (1995): “Minimum wage policy, rural development and poverty alleviation in Malawi”, Development and Change, 26 (4): pp. 729-52

Lustig, N and D. McLeod (1996),'Minimum Wages and Poverty in Developing Countries: Some Empirical Evidence', Washington D.C The Brookings Institute.

MacCurdy, T. and F. McIntyre (2001) Winners and Losers of Federal and State Minimum Wages, Employment Policies Institute, Washington D. C..

Manning, C. (1998), Indonesian Labour in Transition: An East Asian Success Story? Trade and Development Series, Cambridge University Press, Cambridge, 1998.

Manning, C. (2003) Labor Policy and Employment Creation: An Emerging Crisis?, Partnership of Economic Growth-USAID, Report No. 110, Jakarta June 2003 (See http://www.pegasus.or.id/public.html)

Mishel, L., J. Bernstein and E. Rassell (1995), Who Wins With a Higher Minimum Wage?, Economic Policy Institute Briefing Paper, Washington DC.

Neumark, D. and W. Wascher (1992), 'Employment Effects of Minimum and Subminimum Wages: Panel Data on State Minimum Wage Laws', Industrial and Labor Relations Review 46, pp. 55-81

Neumark, D. and W. Wascher (1997), 'Do Minimum Wages Fight Poverty?’ NBER, Working Paper No. 7519.

OECD (1997), 'Making the most of the minimum: statutory minimum wages, employment and poverty’, chapter 2, Employment Outlook, OECD.

Rama, M. (1996), 'Consequences of Doubling the Minimum Wage: the Case of Indonesia', Policy Research Working Paper 1643, The World Bank, Washington D.C.

Saget, C. (2001), 'Is the Minimum Wage an Effective Tool to Promote Decent Work and Reduce Poverty? The Experience of Selected Developing Countries', ILO Employment Paper 2001/13.

Suryahadi, A., W. Widyanti, D. Perwira and S. Sumarto (2003), 'Minimum wage and its Impact on Employment in the Urban Formal Sector', Bulletin for Indonesian Economic Studies, 39 (1), pp. 29-50.

Ravallion, M. (2001),'Growth Inequality, and Poverty: Looking Beyond the Averages', World Development, 29 (11), pp. 1803-1815.

Ravallion, M. (2003), 'Targeted Transfers in Poor Countries: Revisiting the Trade-Offs and Policy Options’, CPRC Working paper No. 26, Washington D.C.

Warr, P. (2004), Globalization, Growth, and Poverty Reduction in Thailand', ASEAN Economic Bulletin, 21 (1), pp 1-18.

Winters, A., N. McCulloch and A. McKay (2004), 'Trade, Liberalization and Poverty: The Evidence So Far', Journal of Economic Literature, 42, pp 72-115. 


\section{Table 1}

Occupational Status of Workers in Indonesia, 2002

\begin{tabular}{lc}
\hline Status & $\begin{array}{c}\text { Number of workers } \\
\text { (in millions) }\end{array}$ \\
\hline Formal employment & 27.8 \\
Of which: & 2.8 \\
--- employers & 25.0 \\
--- regular wage workers & \\
& 63.8 \\
Informal employment & \\
Of which: & 17.6 \\
--- self employed workers & \\
--- self employed with unpaid & 22.0 \\
family workers & \\
--- casual workers in non- & 4.5 \\
agriculture & \\
--- casual workers in & 3.6 \\
agriculture & 16.1 \\
--- unpaid family workers & \\
& 91.6 \\
Total workforce & 9.1 \\
Unemployment & 100.8 \\
\hline Labor force
\end{tabular}

Source: Labor Force survey, 2002

Table 2

Percentage of Households with Low Wage Formal Earners, Indonesia, 2002

\begin{tabular}{lccc}
\hline $\begin{array}{l}\text { Income-poverty } \\
\text { thresholds }\end{array}$ & $\begin{array}{c}\text { Households in } \\
\text { each income- } \\
\text { poverty group }\end{array}$ & $\begin{array}{c}\text { Households with a } \\
\text { Low-wage worker }\end{array}$ & $\begin{array}{c}\text { Distribution of } \\
\text { households with } \\
\text { low-wage workers }\end{array}$ \\
\hline Poor households & 17.4 & 24.9 & 18.4 \\
Near Poor & 33.8 & 23.6 & 34.0 \\
Non-poor & 48.8 & 23.0 & 47.6 \\
households & & & \\
Of which non-poor & & & \\
households with: & 21.5 & 23.2 & \\
---Income-needs & & & \\
ratio 150\% to 200\% & 16.9 & 23.0 & 16.5 \\
---Ratio 200\% to & 10.3 & 22.4 & 9.8 \\
300\% & 100 & 23.5 & 100 \\
---Ratio > 300\% & & & \\
Total & & & \\
\hline
\end{tabular}

Note: Aggregation of households across provincial poverty-income ratios

Source: Susenas 2002 
Table 3

Characteristics of Low Wage Workers by Income-Poverty Ratio

Indonesia 2002

(\% of total low wage workers in each income group)

\begin{tabular}{lccccccc}
\hline $\begin{array}{l}\text { Income-poverty } \\
\text { ratio }\end{array}$ & Youths & Adults & $\begin{array}{c}\text { Less } \\
\text { Educated }\end{array}$ & $\begin{array}{c}\text { More } \\
\text { educated }\end{array}$ & Female & Male & Single \\
\hline $\begin{array}{l}\text { Poor households } \\
\begin{array}{l}\text { Near poor } \\
\text { households }\end{array}\end{array}$ & 32 & 68 & 78 & 22 & 37 & 63 & 42 \\
$\begin{array}{l}\text { Non-poor } \\
\text { households }\end{array}$ & 32 & 68 & 71 & 29 & 35 & 65 & 42 \\
$\begin{array}{l}\text { Of which non-poor } \\
\text { households with: }\end{array}$ & 35 & 65 & 55 & 45 & 41 & 59 & 49 \\
$\begin{array}{l}-- \text { Ratio 1.5 } \\
\text { to 2 }\end{array}$ & 33 & 67 & 59 & 41 & 38 & 62 & 43 \\
--- Ratio 2 \\
to 3
\end{tabular}

Source: Susenas 2002

Teenagers and youths - workers aged 15-24 years

Less educated workers - workers with junior high school or less

Table 4

Additional Costs to Households After the Minimum Wage Hike, Indonesia, 2002-2003 (Rp and US\$ annually)

\begin{tabular}{lcc}
\hline Income-poverty thresholds & Extra household cost* & $\begin{array}{c}\text { Percentage } \\
\text { increase in } \\
\text { household } \\
\text { expenditure }\end{array}$ \\
\hline Poor Households & Rp66,000 or $\$ 7.0$ & $1.3 \%$ \\
Near Poor Households & Rp90,000 or $\$ 10.0$ & $1.3 \%$ \\
Non-Poor Households & Rp194,000 or $\$ 21.0$ & $1.6 \%$ \\
Of which non-poor households: & Rp120,000 or $\$ 13.0$ & $1.4 \%$ \\
---Ratio 150\% to 200\% & Rp170,000 or $\$ 18.0$ & $1.5 \%$ \\
---Ratio 200\% to 300\% & Rp389,000 or $\$ 43.0$ & $1.8 \%$ \\
---Ratio > 300\% & &
\end{tabular}




\section{Table 5}

Winners and Losers from the Minimum Wage Increase

Indonesia, 2002-2003 (Rp. per year net benefits)

\begin{tabular}{|c|c|c|c|c|c|c|}
\hline \multirow{2}{*}{$\begin{array}{l}\text { Per capita- } \\
\text { income relative } \\
\text { to the poverty } \\
\text { line }\end{array}$} & \multicolumn{2}{|c|}{$\begin{array}{c}\text { Share of Households } \\
(\%)\end{array}$} & \multicolumn{4}{|c|}{$\begin{array}{c}\text { Net Benefits/(Costs) } \\
\text { Rp 000s }\end{array}$} \\
\hline & $\begin{array}{l}\text { With Low } \\
\text { Wage } \\
\text { Workers }\end{array}$ & $\begin{array}{c}\text { Without Low } \\
\text { Wage } \\
\text { Workers }\end{array}$ & $\begin{array}{l}\text { With Low } \\
\text { Wage } \\
\text { Workers }\end{array}$ & $\begin{array}{c}\text { Without Low } \\
\text { Wage } \\
\text { Workers }\end{array}$ & $\begin{array}{c}\text { Average net } \\
\text { benefit }\end{array}$ & $\begin{array}{l}\text { Aggregate } \\
\text { net benefits } \\
\text { (Rp billions) }\end{array}$ \\
\hline Poor households & 24.9 & 75.1 & 501 & $(66)$ & 75 & 693 \\
\hline $\begin{array}{l}\text { Near poor } \\
\text { households }\end{array}$ & 23.6 & 76.4 & 544 & (90) & 60 & 1,070 \\
\hline $\begin{array}{l}\text { Non-poor } \\
\text { households } \\
\text { Of which non-poor } \\
\text { households: }\end{array}$ & 23.0 & 77.0 & 446 & (195) & (47) & $(1,184)$ \\
\hline $\begin{array}{l}\text {---Ratio } 150 \% \text { to } \\
200 \%\end{array}$ & 23.2 & 76.8 & 546 & (120) & 35 & 401 \\
\hline $\begin{array}{l}--- \text { Ratio } 200 \% \text { to } \\
300 \%\end{array}$ & 23.0 & 77.0 & 481 & (170) & (20) & $(165)$ \\
\hline ---Ratio > 300\% & 22.4 & 77.6 & 170 & (389) & (264) & $(1,420)$ \\
\hline
\end{tabular}

Net benefits = additional income to household from the minimum wage increase less additional expenditure households must spend as a result of wage-induced price increases. Figures in parentheses are negative numbers. Average net benefits are aggregate net benefits received by the income group divided by number of households in that income group. Aggregate net benefits refer to total net benefits received by households in the income group. 
Table 6

Change in the Number of Households by Status Relative to the Poverty Line, Indonesia, 2002-2003

\begin{tabular}{lcccc} 
Household Group & \multicolumn{2}{c}{2003} & \multicolumn{2}{c}{ Total 2002 } \\
& $\begin{array}{c}\text { Poor } \\
\text { households }\end{array}$ & Near Poor & Non- \\
poor \\
Poor households & 8.7 & 0.5 & 0 & 9.2 \\
Near Poor & 0.4 & 16.8 & 0.6 & 17.8 \\
Non-poor & 0 & 0.6 & 24.6 & 25.2 \\
Total 2003 & 9.1 & 17.9 & 25.2 & 52.2 \\
& & & & \\
\% Change (2002-03) & -1.1 & 0.6 & 0 & \\
\hline
\end{tabular}

Table 7

Winners and Losers from the Minimum Wage Increase When There are Job Losses Indonesia, 2002-2003 (Rp. 000s per year, net benefits/costs)

\begin{tabular}{|c|c|c|c|c|c|c|}
\hline \multirow{2}{*}{$\begin{array}{l}\text { Per capita- } \\
\text { income relative } \\
\text { to the poverty } \\
\text { line }\end{array}$} & \multicolumn{3}{|c|}{ With no job losses } & \multicolumn{3}{|c|}{ With job losses } \\
\hline & $\begin{array}{l}\text { Households } \\
\text { With Low } \\
\text { Wage } \\
\text { Workers } \\
\end{array}$ & $\begin{array}{c}\text { Households } \\
\text { Without Low } \\
\text { Wage } \\
\text { Workers }\end{array}$ & $\begin{array}{c}\text { Average net } \\
\text { benefits }\end{array}$ & $\begin{array}{l}\text { Households } \\
\text { With Low } \\
\text { Wage } \\
\text { Workers }\end{array}$ & $\begin{array}{c}\text { Households } \\
\text { Without Low } \\
\text { Wage } \\
\text { Workers }\end{array}$ & $\begin{array}{c}\text { Average } \\
\text { net benefits }\end{array}$ \\
\hline Poor households & 501 & (66) & 75 & 409 & (55) & 61 \\
\hline $\begin{array}{l}\text { Near poor } \\
\text { households } \\
\text { Non-poor }\end{array}$ & 544 & (90) & 60 & 452 & (75) & 49 \\
\hline $\begin{array}{l}\text { Non-poor } \\
\text { households } \\
\text { Of which non-poor }\end{array}$ & 446 & (195) & $(47)$ & 387 & () & (36) \\
\hline $\begin{array}{l}\text {---Ratio } 150 \% \text { to } \\
200 \% \\
\text {---Ratio } 200 \% \text { to }\end{array}$ & 546 & (120) & 35 & 467 & (100) & 31 \\
\hline $\begin{array}{l}300 \% \\
\text {---Ratio > 300\% }\end{array}$ & $\begin{array}{l}481 \\
170\end{array}$ & $\begin{array}{l}(170) \\
(389)\end{array}$ & $\begin{array}{l}(20) \\
(264)\end{array}$ & $\begin{array}{l}419 \\
161\end{array}$ & $\begin{array}{l}(141) \\
(326)\end{array}$ & $\begin{array}{l}(12) \\
(217)\end{array}$ \\
\hline
\end{tabular}

Net benefits $=$ additional income to household from the minimum wage increase less additional expenditure households must spend as a result of wage-induced price increases. Figures in parentheses are negative numbers 


\section{Figure 1 \\ Steps in Developing Simulations of Distributional Effects}

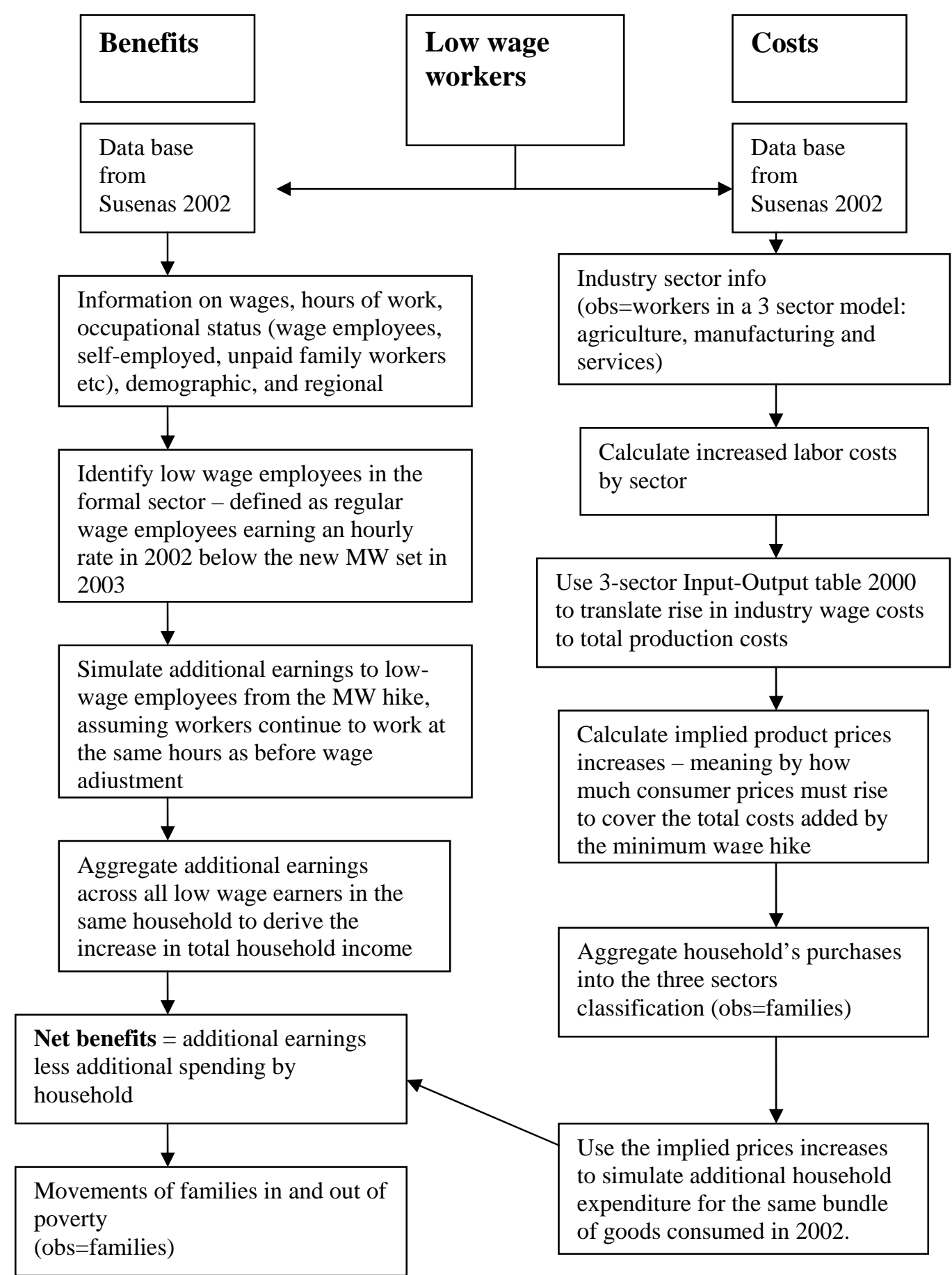

Source: Adapted from Macurdy \& McIntyre (2001: Figure 3.2). 
Figure 2

Percentage Distribution of Benefits by Income Groups, Relative to the Poverty Line Indonesia, 2002-2003

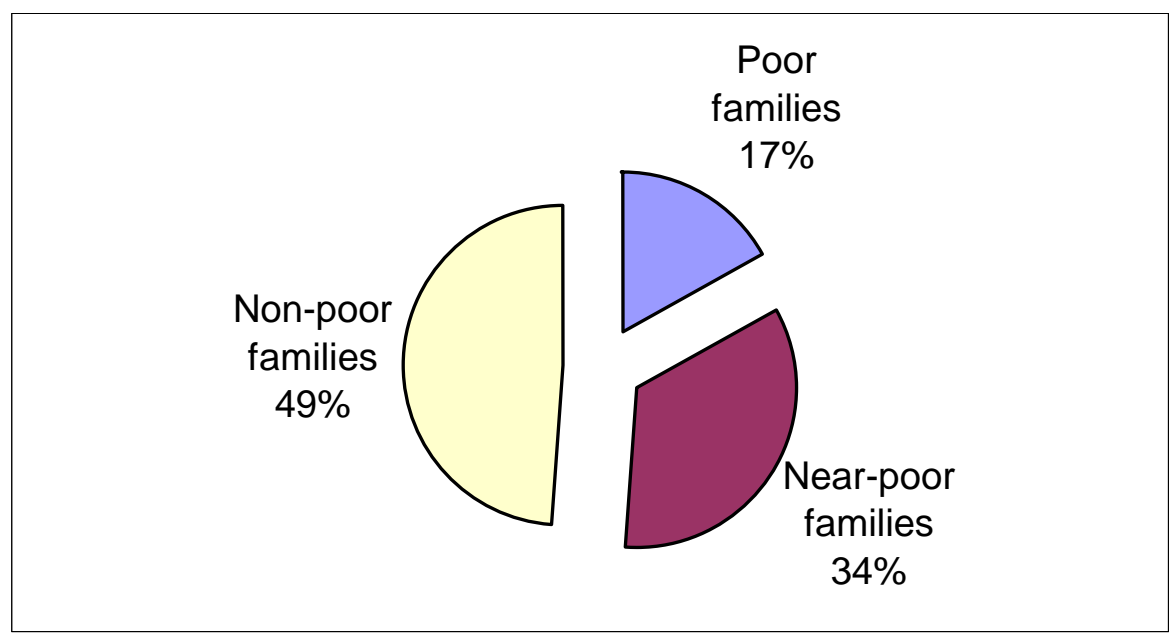

Note: Aggregation of households across provincial poverty lines Source: Susenas 2002

Figure 3

Percentage Distribution of Costs by Income Groups, Relative to the Poverty Line Indonesia, 2002-2003

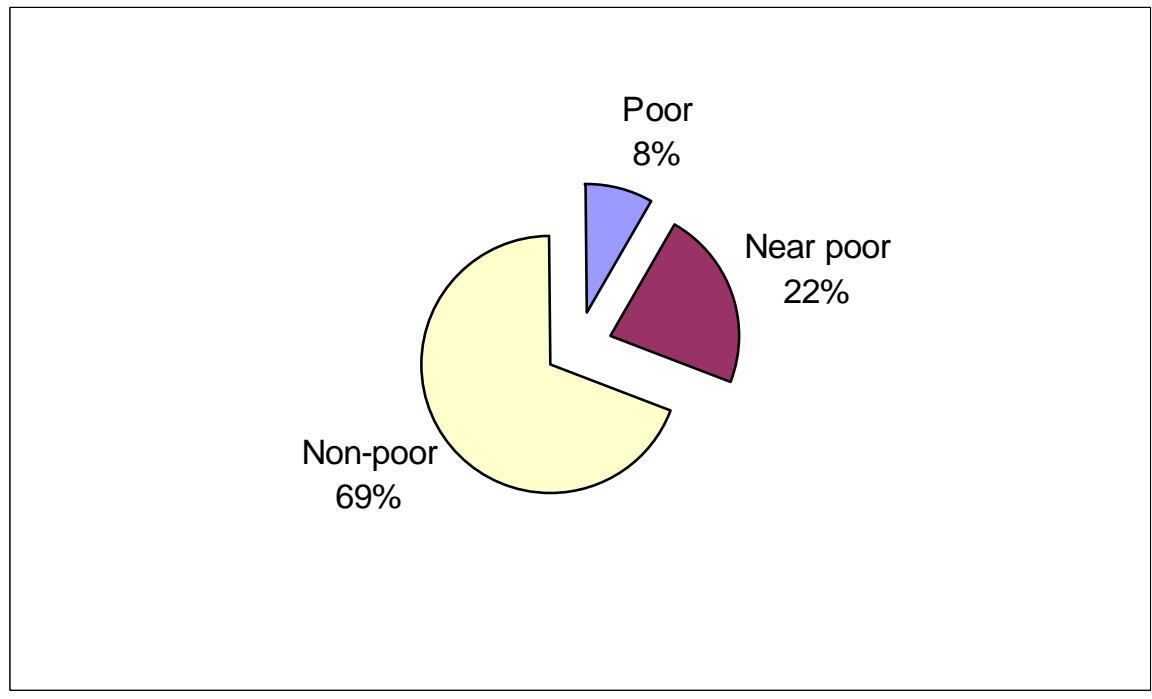


Annex 1

Distribution of Benefits under Different Assumptions about Compliance, Spillovers and Employment Losses, Indonesia 2002-2003

\begin{tabular}{|c|c|c|c|c|c|}
\hline $\begin{array}{l}\text { Income } \\
\text { group }\end{array}$ & $\begin{array}{l}\text { Percentage } \\
\text { households } \\
\text { in each } \\
\text { category } \\
\text { (Table 3) }\end{array}$ & $\begin{array}{l}\text { 1. Benefits } \\
\text { under } \\
\text { incomplete } \\
\text { compliance/no } \\
\text { job losses } \\
\text { (Figure 2) }\end{array}$ & $\begin{array}{l}\text { 2. Benefits } \\
\text { under } \\
\text { incomplete } \\
\text { compliance/ } \\
\text { employment } \\
\text { losses }\end{array}$ & $\begin{array}{l}\text { 3. Benefits } \\
\text { under full } \\
\text { compliance/ } \\
\text { no job } \\
\text { losses }\end{array}$ & $\begin{array}{l}\text { 4. Benefits } \\
\text { under full } \\
\text { compliance } \\
\text { plus positive } \\
\text { spillovers/no } \\
\text { job losses }\end{array}$ \\
\hline $\begin{array}{l}\text { Poor } \\
\text { households }\end{array}$ & $17.4 \%$ & $16.8 \%$ & 16.3 & $17.6 \%$ & $17.0 \%$ \\
\hline $\begin{array}{l}\text { Near poor } \\
\text { households }\end{array}$ & $33.8 \%$ & $34.4 \%$ & 34.0 & $30.1 \%$ & $30.0 \%$ \\
\hline $\begin{array}{l}\text { Non-poor } \\
\text { households }\end{array}$ & $48.8 \%$ & $48.8 \%$ & 49.7 & $52.2 \%$ & $53.0 \%$ \\
\hline
\end{tabular}

Notes:

Full compliance means all sub-minimum wage workers in 2002 receive the new minimum wage in 2003.

Spillovers to wage workers refer to those workers whose wages in 2002 were up to $50 \%$ higher than the new minimum wage in 2003. We assume these workers receive a wage increase equal to the percentage increase in the minimum wage in 2003.

Simulations \#1,\#3, and \#4 assume no job losses. Simulation \#2 assumes incomplete compliance as in simulation 1 but includes job loses among less educated, low wage workers (see text). 


\section{Endnotes}

${ }^{1}$ Research Associate and Senior Fellow, Division of Economics, Research School of Pacific and Asian Studies, ANU, Canberra. Earlier drafts of this paper was presented at a seminar in the Division of Economics, Research School of Pacific Studies, ANU in March 2005 and at a Development Economics Workshop at the University of New South Wales, Sydney in June 2005. The authors are very grateful for valuable comments made on the paper at both meetings. The authors would also like to thank Choesni Tubagus for data processing assistance. We would also like to thank ICSEAD for a research grant. The normal disclaimers apply.

${ }^{2}$ See especially Rama (1996), Alatas \& Cameron (2003), Suryahadi, Widyanti, Perwira \& Sumarto (2003), and Harrison \& Scorse (2004).

${ }^{3}$ For a summary of the previous studies see the OECD (1997) study on minimum wages

${ }^{4}$ Baker, Benjamin \& Stanger (1999) suggest that the conflicting findings on employment effects in recent studies can be reconciled by distinguishing between short term effects and longer term adjustment in employment. They show that little or no employment losses occur in the short run (Card \& Kruger findings), while job losses occur in the longer term as firms substitute capital for labor in low wage sectors (Neumark \& Wascher, 1992).

${ }^{5}$ Adjustments are made annually, based on recommendations from the district heads, who in turn receive inputs from employer groups and major unions in their region.

${ }^{6}$ For example, the monthly absolute value of the minimum living needs for all Indonesia was substantially higher than average per capita expenditure per month, and almost three times the per capita poverty line in urban areas in 2001 (Manning, 2003).

${ }^{7}$ Thus, official data reported by the Ministry of Manpower, find that increases in the KHM were around 25\% (averaged across all provinces) in both 2000 and 2001. In contrast, December on December CPI increases were estimated at 13\% by the Central Board of Statistics in each of the same two years.

${ }^{8}$ Aside from MacCurdy \& McIntyre, several other empirical studies for advanced nations have simulated the expected benefits of increases in minimum wages by household income group. See for example Sutherland (1995), Horrigan \& Mincy (1993), and Neumark (1997). Except for MacCurdy \& McIntyre, none of these studies incorporated the price effects borne by consumers, although some studies do examine employment effects.

${ }^{9}$ While research is limited to the U.S., several studies have analyzed the impact of a minimum wage increase on prices. Using either an Input-Output model or a CGE model, they show that some proportion of minimum wage increase will pass through to higher consumer prices. For example, the Card \& Krueger study on New Jersey/Pennsylvania (1995: p54) observed "prices rose $4 \%$ faster as a result of the minimum wage increase."

10 This also includes workers earning a wage below the minimum rate in 2002, since there are spillovers to wage workers at the bottom of the wage distribution (Saget, 2001). We assume that these workers benefit by the same percentage increase as the rise in the statutory rate.

${ }^{11}$ In January 2003 the Indonesian government exempted all minimum wage earners from income tax. Thus, in this study it is not necessary to consider the tax implications of minimum wage increases for these workers and their families.

${ }^{12}$ We proxy household income by consumption, owing to limitations in the non-wage data reported in the income module of the SUSENAS. There is a consensus among researchers familiar with the SUSENAS that the non-wage component in the income module may be misreported because of difficulties in collecting the data on the informal or non-wage sector.

${ }^{13}$ We adopt this classification used by Burkhauser, Couch \& Wittenburg (1996) in their note on minimum wages and poverty in the U.S.

${ }^{14}$ This new approach was introduced in the Manpower Act, No. 13, 2003.

${ }^{15}$ The distribution of benefits depicted in Figure 3 assumes incomplete compliance with minimum wage legislation. To examine whether full compliance with the legislation would bring greater benefits to poor households, simulations were undertaken assuming all sub-minimum wage workers in 2002 received the new minimum wage in 2003. These results are presented in Annex 1. While full compliance would obviously increase aggregate earnings of low wage workers, Annex 1 shows that the distribution of benefits does not change much.

${ }^{16}$ Direct labor costs are the increase in labor costs in that sector. Indirect labor costs are traced through higher intermediate input prices due to minimum wage increases.

${ }^{17}$ According to the I-O table, $2.4 \%$ of agriculture output is exported, $27 \%$ of manufactured goods are exported and $9.7 \%$ of services are exported.

${ }^{18}$ For example, poor families spent about $47 \%$ of their budget on food items, $30 \%$ on manufactured goods and $23 \%$ on utilities and services. Families with income-needs ratio above $300 \%$ spent $21 \%$ of their budget on food items, $31 \%$ on manufactured goods and $48 \%$ on utilities and services.

19 We are interested in how real household consumption has shifted relative to the real poverty line. Thus, we deflate simulated, nominal household incomes in 2003 by the 'implicit' incremental price increases listed in table 4 , in order to derive real incomes in 2002 prices. We next compare these real incomes with the 2002 poverty line. This enables an estimate of the number of households that have escaped poverty, and the number that have entered into poverty. 
${ }^{20}$ For example, Warr (2004) found that the majority of minimum wage workers live in non-poor households in a paper on Thailand, although he did not carry out simulations on the impact of increases in minimum wages on income distribution and poverty.

${ }^{21}$ See, for example, Saget (2001) and Lustig \& McLeod (1997). Both studies apply regression analysis to a cross-sectional sample of developing countries. 